\title{
The strokes that killed Churchill, Roosevelt, and Stalin
}

\author{
Rohaid Ali, BA, Ian D. Connolly, MS, Amy Li, BA, Omar A. Choudhri, MD, \\ Arjun V. Pendharkar, MD, and Gary K. Steinberg, MD, PhD \\ Department of Neurosurgery and Stanford Stroke Center, Stanford University School of Medicine, Stanford, California
}

\begin{abstract}
From February 4 to 11, 1945, President Franklin D. Roosevelt of the United States, Soviet Union Premier Joseph Stalin, and British Prime Minister Winston Churchill met near Yalta in Crimea to discuss how post-World War II (WWII) Europe should be organized. Within 2 decades of this conference, all 3 men had died. President Roosevelt died 2 months after the Yalta Conference due to a hemorrhagic stroke. Premier Stalin died 8 years later, also due to a hemorrhagic stroke. Finally, Prime Minister Churchill died 20 years after the conference because of complications due to stroke. At the time of Yalta, these 3 men were the leaders of the most powerful countries in the world. The subsequent deterioration of their health and eventual death had varying degrees of historical significance. Churchill's illness forced him to resign as British prime minister, and the events that unfolded immediately after his resignation included Britain's mismanagement of the Egyptian Suez Crisis and also a period of mistrust with the United States. Furthermore, Roosevelt was still president and Stalin was still premier at their times of passing, so their deaths carried huge political ramifications not only for their respective countries but also for international relations. The early death of Roosevelt, in particular, may have exacerbated post-WWII miscommunication between America and the Soviet Union-miscommunication that may have helped precipitate the Cold War.
\end{abstract}

http://thejns.org/doi/abs/10.3171/2016.4.FOCUS1575

KEY WORDS stroke; Franklin D. Roosevelt; Winston Churchill; Joseph Stalin

$\mathrm{B}$ Y February of 1945, it had become strongly apparent to the Allied Powers, which included the United States, Great Britain, and the Soviet Union, that Nazi Germany was crumbling and on its way to defeat. ${ }^{45}$ On the eastern front, Soviet Union troops had recaptured Poland and seemed virtually unstoppable in their march toward Berlin; in the west, the successful completion of Operation D-Day had allowed millions of Allied troops to begin their own campaign of recapturing France and pressuring Germany's western front. ${ }^{4,16}$ The close of a war that had left tens of millions dead on continental Europe seemed firmly within reach. ${ }^{11}$

What was less clear was how post-World War II (WWII) Europe should be organized and how the Allied Powers would deal with the still grave threat of Imperial Japan in the Pacific..$^{45}$ Thus, a conference was organized for February 4 to 11, 1945, near Yalta in Crimea to be attended by the leaders of the 3 major Allied Powers: President Franklin D. Roosevelt of the United States, British Prime Minister Winston Churchill, and Soviet Union Premier Joseph Stalin (Fig. 1). ${ }^{22}$ At this point in the war, the Soviet
Union was largely uninvolved in the Pacific theater; to enlist the Soviet Union's assistance against Japan, Roosevelt guaranteed tracts of land in Northeast Asia to the Soviets. ${ }^{45}$ Additionally, Joseph Stalin conceded that in exchange for a sphere of influence over Eastern Europe, the countries there would be able to exercise self-determination via free and fair democratic elections following the war. ${ }^{13,25,45}$

Within 20 years after this historic agreement, all 3 major participants had died of a stroke. ${ }^{15,26,43}$ The first of these deadly strokes-that of Roosevelt-would prove to be among the most consequential in human history, as subsequent interactions between the succeeding Truman administration and Stalin's Soviet Union were acrimonious. ${ }^{45}$ This tension would eventually develop into a decades-long conflict known as the Cold War. The strokes that killed Stalin and Churchill also proved to have varying degrees of historical significance. In the subsequent sections, we intend to examine the interaction of domestic politics and international geopolitics with the deteriorating health and ultimate death due to the strokes of Roosevelt, Stalin, and Churchill. 


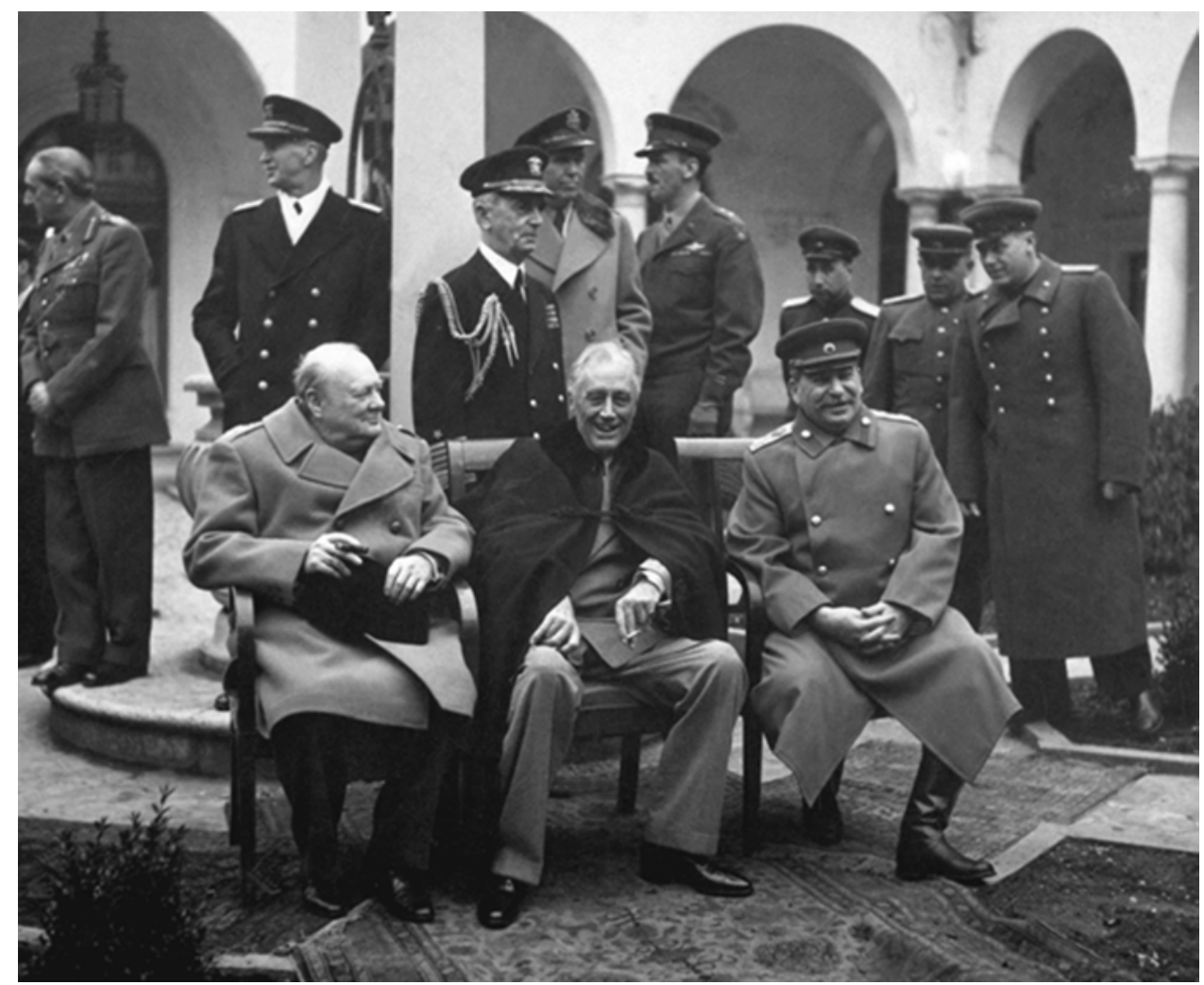

FIG. 1. From left, Prime Minister Churchill, President Roosevelt, and Premier Stalin at the 1945 Yalta Conference to discuss plans for a post-WWII planet. Within 20 years of this conference, all of these men had died. Source: http://en.wikipedia.org/wiki/Yalta Conference\#mediaviewer/File:Yalta_Conference_(Churchill,_Roosevelt,_Stalin)_(B\%26W).jpg. Public domain.

\section{Franklin D. Roosevelt}

President Franklin Roosevelt's death came on April 12, 1945, just 2 months after the Yalta Conference, when he was sitting for a portrait in Warm Springs, Georgia. Midway through the artist's work (Fig. 2), he proclaimed "I have a terrific headache," and he collapsed to the floor. ${ }^{36}$ His primary cardiologist, Dr. Howard G. Bruenn, rushed to evaluate him; the president's blood pressure was 300/190 mm Hg. ${ }^{7}$ Within a few hours, Roosevelt was pronounced dead; the cause: an occipital hemorrhagic stroke?

The death of Roosevelt shocked a public that widely pictured him to be in excellent shape, but the reality was that he had been in declining health for many years. ${ }^{35,42}$ In 1937 he had hypertension, with a blood pressure of 162/98 mm Hg.7 In April 1944, about 1 year before his death, Roosevelt's blood pressure had climbed to 230/126 $\mathrm{mm}$ Hg. ${ }^{7}$ Radiographs showed cholesterol gallstones, and an electrocardiogram indicated an enlarged heart. ${ }^{2}$ Later that year in November, the month he was reelected to his fourth term as president, his blood pressure was 250/150 $\mathrm{mm} \mathrm{Hg} .{ }^{7} \mathrm{He}$ began complaining of a loss of appetite. ${ }^{2}$ By January of the following year, his hands shook uncontrollably, and he had lost a considerable amount of weight. ${ }^{2}$ During the Yalta Conference the following month, Roosevelt's blood pressure reached 260/150 mm Hg. ${ }^{7}$ This was when Dr. Lord Moran, personal physician to Winston Churchill, uttered the prophetic prognosis, "I give him only a few months to live." 8
Roosevelt's compromised health during the Yalta Conference may have weakened his mental capacity and, in turn, negotiating ability with Stalin. William Harriman, the American special envoy to Europe, noted, "At Yalta,

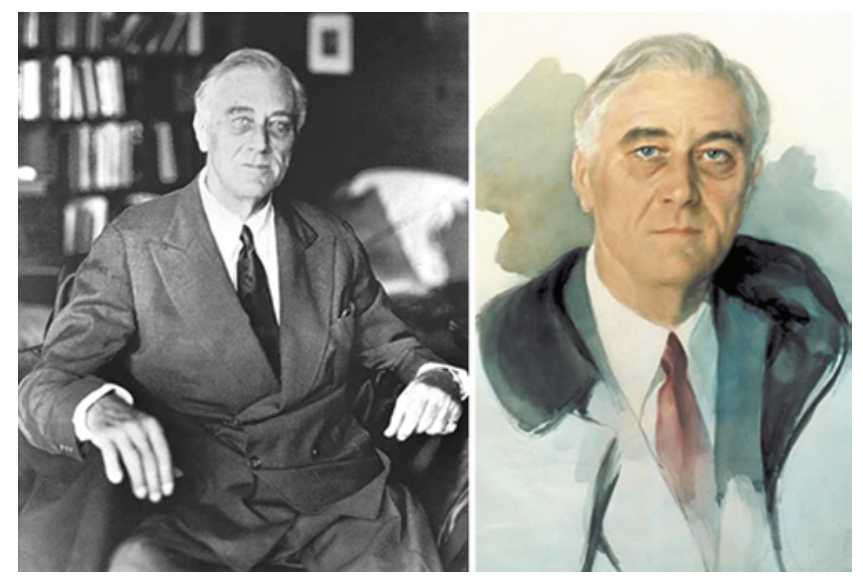

FIG. 2. This is the Unfinished Portrait by Elizabeth Shoumatoff. On April 12, 1945, Shoumatoff was painting this portrait of Roosevelt when he suffered a fatal hemorrhagic stroke, leaving the rest of the artwork incomplete. Source: http://en.wikipedia.org/wiki/Unfinished_portrait_ of_Franklin_D._Roosevelt\#mediaviewer/File:FDR_unfinished.jpg. Photograph CC BY 2.0 (http://creativecommons.org/licenses/by/2.0/). Courtesy of the FDR Presidential Library \& Museum. Painting courtesy of Roosevelt's Little White House. 
I believe, [Roosevelt] didn't have the strength to be quite as stubborn as he liked to be. I suppose that if FDR has been in better health, he might have held out longer and got his way on a number of detailed points." 23 When Roosevelt returned to the United States, he delivered a speech to Congress exalting the successes of the Yalta Conference, describing how the Allied Powers were united on the principle that all nations deserve the right to exercise self-determination. ${ }^{41}$ However, shortly thereafter, Stalin reneged on this agreement. He falsely accused the United States and United Kingdom of creating an exclusive peace with Germany, and he raised tensions further when he started disallowing Eastern European countries from participating in free elections. ${ }^{2}$ On March 23, 1945, Roosevelt said to an aid, "We can't do business with Stalin. He has broken every one of the promises he made at Yalta." ${ }^{23}$

Roosevelt began working to normalize relations with Stalin, but the cerebral hemorrhage would take his life before he could succeed. ${ }^{2}$ Three days after Roosevelt's passing, Nazi Germany celebrated by describing the fatal stroke as a miracle. ${ }^{1}$ Meanwhile, newly appointed President Harry Truman began settling himself into the job. Truman oversaw American military operations in Europe until Germany's surrender on May 8, 1945, and he effectively led the Allies to victory against Imperial Japan in the Pacific. However, the Truman administration was never successful in normalizing relations with Moscow; left unchecked, the Soviet Union continued to exert-in discordance with internationally agreed-upon principles-a dominating influence over newly liberated Eastern European nations. ${ }^{45}$

Given the magnitude of Roosevelt's poor health in the months preceding his death, the fact that the American public was not made aware raises important ethical questions. Roosevelt's personal cardiologist, Dr. Bruenn, was familiar with the rapidly declining health of the president during his last year of life. However, another of his physicians made public statements during this same time period that Roosevelt's health was "excellent." ${ }^{35}$ Furthermore, when Roosevelt was delivering his speech to Congress in 1945 following the Yalta Conference, he needed to remain seated the entire time; rather than attributing his inability to deliver a standing speech as being due to his failing health, he blamed it instead on fatigue from travel (Fig. 3). ${ }^{41}$ This lack of transparency toward the American public and to other groups in government may have lulled everyone into thinking that Roosevelt was healthy and foreign policy was under control, when in reality Roosevelt was deathly sick and American relations with the Soviet Union were rapidly deteriorating. One analyst wrote that the potent mix of Roosevelt's poor mental and physical health, and also the ignorance of those around him of the Soviet Union's rise, caused a "hiatus" in effective American leadership. ${ }^{24}$ While certainly debatable, this analyst went on to state that this hiatus created the conditions that allowed "the betrayal of the Poles, the imposition of Communist governments in Eastern Europe, the Czechoslovak coup, and, on the other side of the world, the loss of China and the invasion of South Korea." 24

\section{Joseph Stalin}

Both his contemporaries and subsequent historians

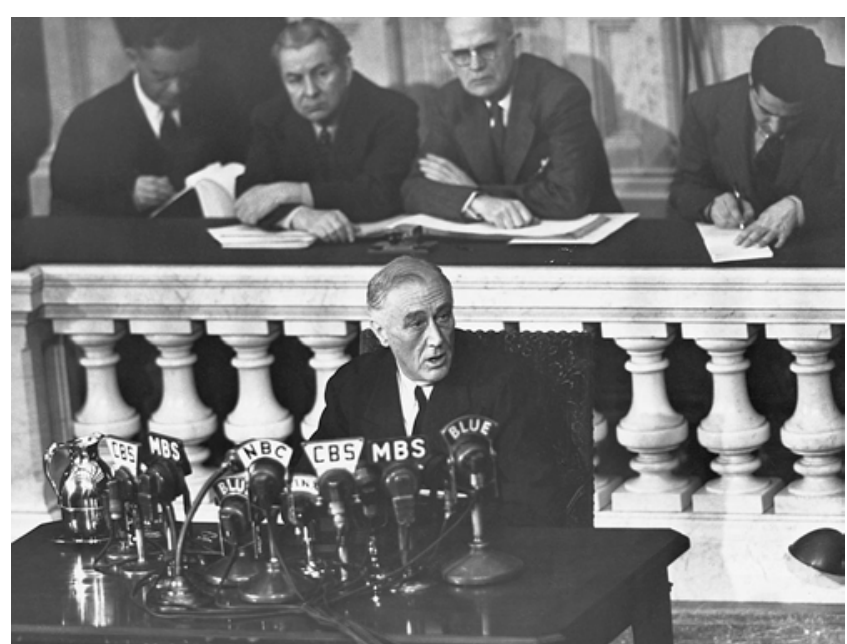

FIG. 3. Roosevelt appears seated as he delivers a speech before Congress following the Yalta Conference. Photographer Bettman/Bettman Collection/Getty Images.

have described Joseph Stalin as being unquestionably competent around the time of WWII. In 1937 his doctor wrote that Stalin had "devilish, cunning, and slyness as well as an astonishing knowledge of the human mind with all its weaknesses. He was headstrong, consistent, and had extraordinary willpower and nerves of iron." ${ }^{\prime 4}$ In 1945 a contemporary said that his "Russian vocabulary was rich and his manner of expression very vivid and plastic, and replete with Russian proverbs and sayings." 12 Stalin was famously blindsided by Germany's offensive early in WWII, but his subsequent management of Red Army affairs and his success at the Yalta Conference and other international meetings in advancing Soviet interests demonstrated his shrewdness. Russian historian Roy Medvedev wrote of Stalin that he "was without a doubt mentally competent and fully aware of what he was doing." 32

Stalin experienced an array of health problems throughout his life, and eventually these came to seriously affect his physical and mental abilities. In 1922 he started experiencing headaches. ${ }^{39}$ In 1934 he might have developed high blood pressure, and in 1937 he might have experienced a transient ischemic attack that disrupted his speech..$^{32,38}$ Stalin, a heavy smoker, suffered from atherosclerosis; on June 24, 1945, he experienced a mild stroke during the WWII victory parade in Moscow, and in October he suffered a major heart attack. ${ }^{34}$ In 1947 he experienced another mild stroke, and in 1948 a severe heart attack left him physically incapacitated for half a year (Fig. 4).29,32

Stalin's cerebrovascular health problems came to a head in 1953 when he experienced a fatal hemorrhagic stroke. On the night of February 28, Stalin invited members of his inner circle for dinner in a private residence near Moscow. After a night of heavy drinking, the party disbanded at 4 AM. However, the next day Stalin did not leave his quarters. Fear prevented his aides from entering his room, but as the day wore on, they became increasingly concerned. Finally, at 11 PM members of the Politburo entered Stalin's quarters to find him on the floor, incoherent and drenched in his own urine. His right arm and leg were paralyzed, 


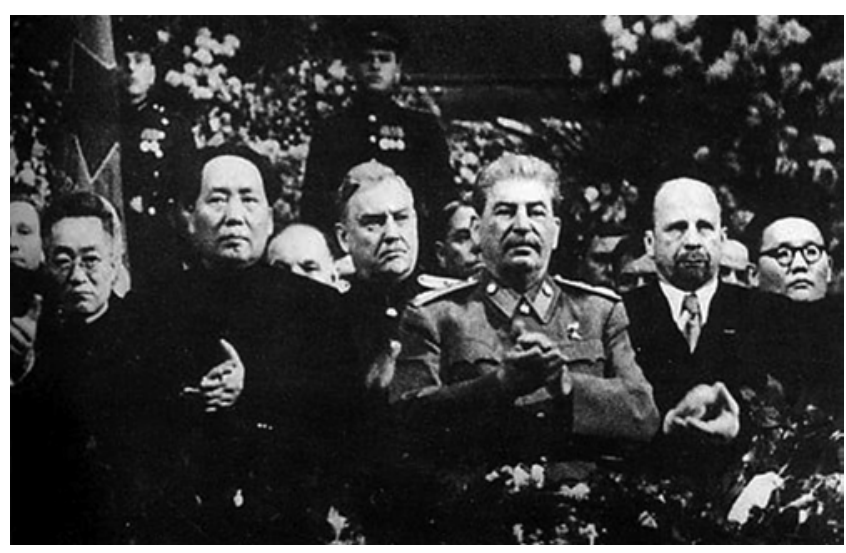

FIG. 4. Joseph Stalin and Mao Zedong at a ceremony arranged for Stalin's 71st birthday in Moscow in December 1949. Source: http:// commons.wikimedia.org/wiki/File:Mao,_Bulganin,_Stalin,_Ulbricht_ Tsedenbal.jpeg. Public domain.

and he had a right Babinski reflex..$^{14}$ Over the next day his blood pressure climbed to $210 / 120 \mathrm{~mm} \mathrm{Hg} .{ }^{14}$ Doctors were summoned, but his condition continued to deteriorate over the subsequent days. On March 3 he lost consciousness permanently, on March 4 he vomited blood, and on March 5 he died with an official time of death of 9:50 PM. ${ }^{14}$

Stalin's death changed the course of Russian history. His regimen was murderous; a major Soviet paper declared in 1989 that, under it, "20 million died in labor camps, forced collectivization, famine, and executions." ${ }^{28}$ Stalin was notoriously paranoid, murdering many Red Army generals and members of his inner circle whom he perceived to be a threat. Some have attributed these actions to a psychiatric paranoid personality disorder, perhaps exacerbated by his declining cerebrovascular health. ${ }^{21}$ Indeed, the fact that it took so long for members of Stalin's Politburo to enter his room following his stroke is a reflection of this fear that he had instilled in them. Because Stalin had not designated a successor, the immediate aftermath of his death was an internal struggle for power. ${ }^{20}$ The Council of Ministers and the Presidium of the Supreme Soviet had initially announced the formation of collective leadership and immediately released anyone arrested in Stalin's last days as well as thousands of political prisoners from gulag labor camps. ${ }^{33,34}$ Hence, it appeared that Moscow was instantly ready to turn away from the harsh policies and repression characteristic of Stalin's rule, although it was also possible that the leadership was persuaded to do so because the high number of prisoners represented a wasteful and inefficient use of resources. ${ }^{30}$

Nikita Khrushchev, who maneuvered his way to become Stalin's successor, continued to reinforce the concept of "de-Stalinization." On February 25, 1956, during a closed session of the 20th Party Congress of the Communist Party of the Soviet Union, Premier Nikita Khrushchev (Fig. 5) boldly delivered his famed speech titled "On the Cult of Personality and Its Consequences," in which he criticized Stalin's purges and personality cult and called for a return to the traditional ideals of communism. ${ }^{34}$ Khrushchev may have only delivered this speech to consolidate his own power. Nevertheless, the official denouncement

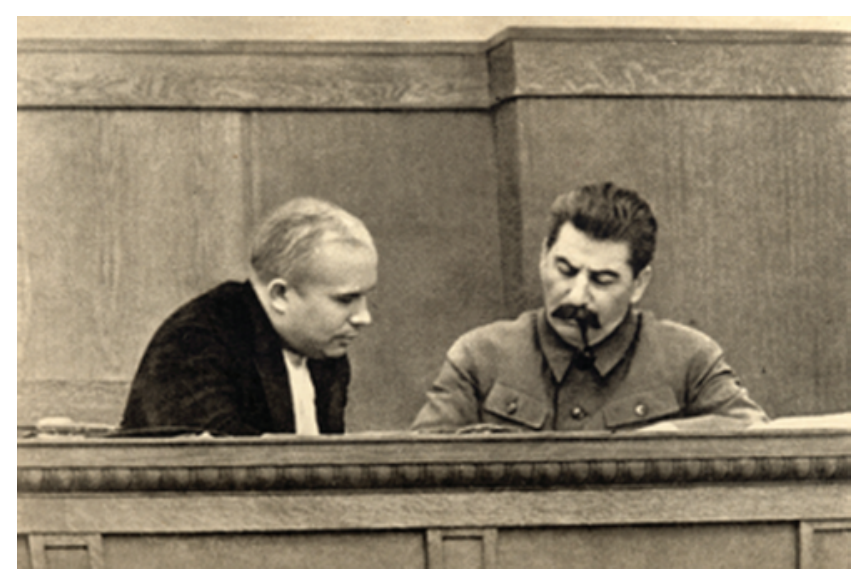

FIG. 5. Joseph Stalin meeting with Nikita Khrushchev in 1936. Two decades later, Khrushchev delivered a speech called "On the Cult of Personality and Its Consequences" that denounced the purges that Stalin conducted during his reign and also the personality cult with which he surrounded himself. Source: http://commons.wikimedia.org/ wiki/File:Joseph_Stalin_and_Nikita_Khrushchev,_1936.jpg. Public domain.

of Stalin's purges offered great relief to those living in the Soviet Union. The death of Stalin therefore marked the end of an era of a hyper-repressive regimen and allowed opportunities for domestic change characterized by less oppressive policies and increased emphasis on consumer industries. ${ }^{31}$ A domestic de-Stalinization, however, was not necessarily accompanied by a de-Stalinization in foreign policy, as foreign policy patterns were arguably more a continuation than a change after Stalin's death. ${ }^{17}$

\section{Winston Churchill}

Winston Churchill was both the last of the 3 major participants at Yalta to pass away and the only one to do so while not holding public office. He lost reelection as prime minister in July 1945, shortly after the conclusion of WWII. Churchill remained active in British politics for a number of years, however. From 1945 until 1951 he served as the leader of the opposition party. In 1951 he won election again as prime minister, and he held this post until his resignation in April 1955 (Fig. 6). He continued on in Parliament, but in 1964 he officially left public office for good and spent his last year at his home in Hyde Park Gate in London. ${ }^{5}$

As was the case with Stalin and Roosevelt, Churchill suffered from hypertension for a number of years before his death. After a mild stroke in 1949, his blood pressure was recorded to be about $160 / 90 \mathrm{~mm} \mathrm{Hg}$. ${ }^{6}$ In consulting a physician, he admitted to smoking about 13 cigars per day and having 3 brandies after dinner. ${ }^{6}$ Four years later on June 24, 1953, Churchill suffered a more serious stroke, which caused his face to slightly droop and his speech to become somewhat slurred. ${ }^{6}$ His blood pressure rose to 170/90 mm Hg. ${ }^{6}$ His health problems would continue to worsen, and because he no longer trusted his own physical abilities, Churchill stepped down as prime minister on April 5, 1955. ${ }^{5}$ In 1959 Churchill lost consciousness while taking a bath in his home in Hyde Park Gate. By 1961 he admitted to his doctor that he lost some emotional self-con- 


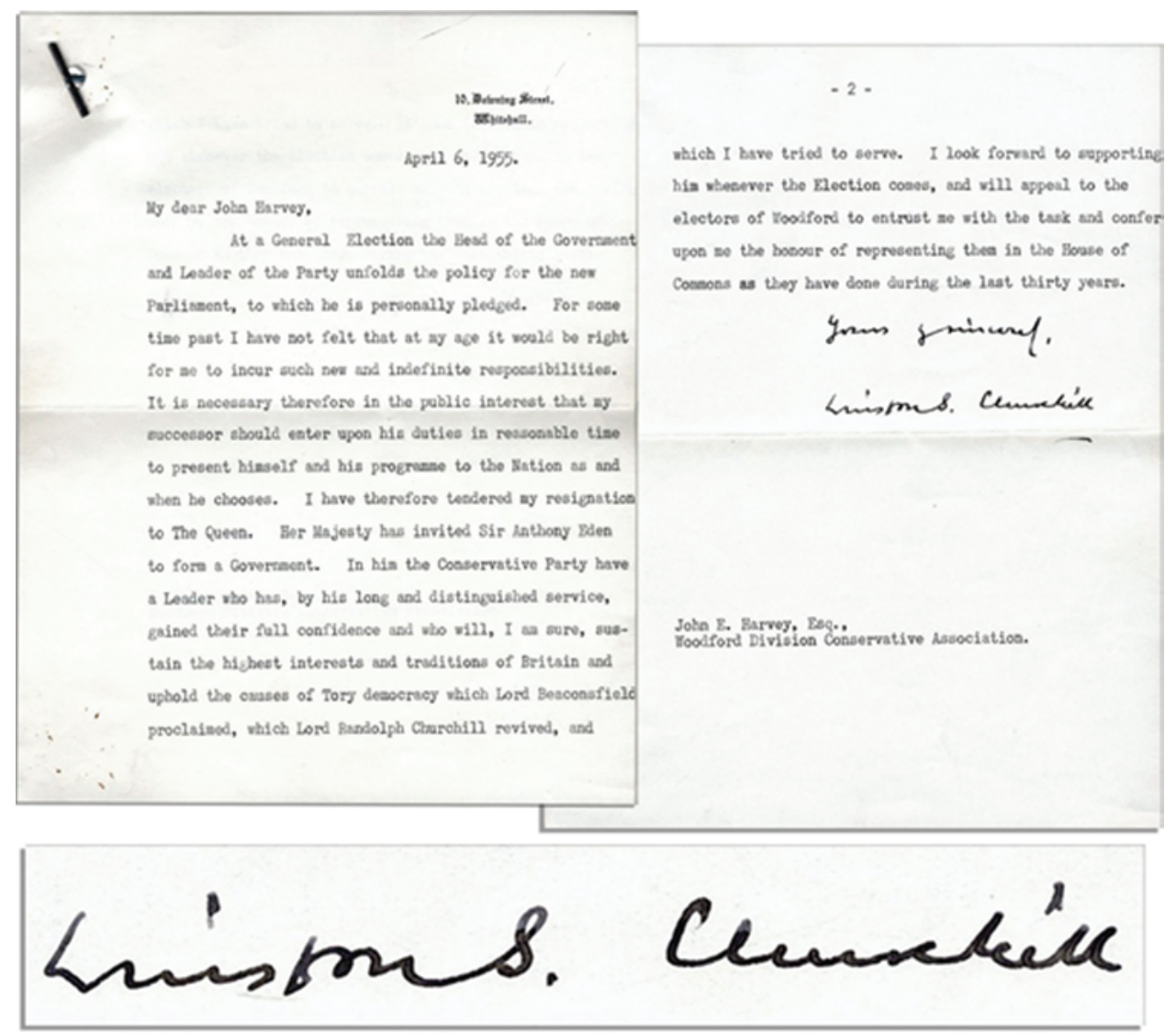

FIG. 6. Churchill's letter of resignation as prime minister. Source: http://www.businessinsider.com.au/winston-churchill-resignationletter-2014-3. Public domain.

trol and had moments of extreme anger and rage toward his assistants. ${ }^{6}$ He developed depression, and sensing himself no longer fit to hold any public office, Churchill left Parliament in 1964 (Fig. 7). ${ }^{5}$ On January 11, 1965, his health took a rapid downward trajectory. He was unable to feed himself or swallow solid foods. His doctor described him as "someone in deep sleep" and diagnosed him as having a terminal episode of cerebral ischemia ${ }^{6}$ Churchill's family declined nasal feedings, so he went without nourishment for 13 days until January 24, the day he died. ${ }^{6}$

Given the stepwise departure from government before his death, Churchill's resignation from his position as prime minister is perhaps the most abrupt and influential event in his gradual decline. Anthony Eden, deputy of Churchill, was chosen to be his successor. Considered by some to be one of Britain's least successful prime ministers, ${ }^{3}$ Eden held the position for less than 2 years (19551957). His term in office is most widely known for the Suez Crisis in which Britain colluded with French and Israeli allies to invade Egypt without the approval of the United States. The deceptive maneuvers to disguise the invasion severely hurt Eden's reputation as well as foreign relations with the United States, led at the time by President Eisenhower. The crisis eventually led to Eden's resignation in 1957. Evidence points toward Churchill's disapproval of the manner in which the Suez Crisis was managed. He privately expressed his disappointment in a letter to a pub- lisher, and his wife believed that his subsequent trips to the United States were made partially in an attempt to repair relations with the United States. ${ }^{9,18}$ Having been wartime colleagues with Eisenhower, Churchill most likely would not have employed the same deception as Eden. Indeed, it was Churchill who in 1946 coined the term "special relationship," a phrase still in use today to describe the close connection and cooperativeness between the two nations.

In addition to fueling a period of mistrust with the United States, Britain's handling of the Egyptian Suez Crisis fueled chaos in the region, which may have benefited the Soviet Union. Siding with Egypt, the Soviet Union threatened to send troops and launch attacks against Britain, France, and Israel if their invasion was not stopped. At the same time, Khrushchev hinted at the nuclear capabilities of the Soviet Union. Although the crisis eventually came to a close due to both political and economic pressures, the Soviet Union perceived the role it had played as a triumph. Khrushchev further realized the utility of nuclear blackmail in imposing foreign policy. ${ }^{19}$ While arguable, the disorderly resolution of the crisis that followed allowed the Soviet Union to secure additional influence in the Middle East.

\section{Conclusions}

The Yalta Conference ranks among the most impor- 


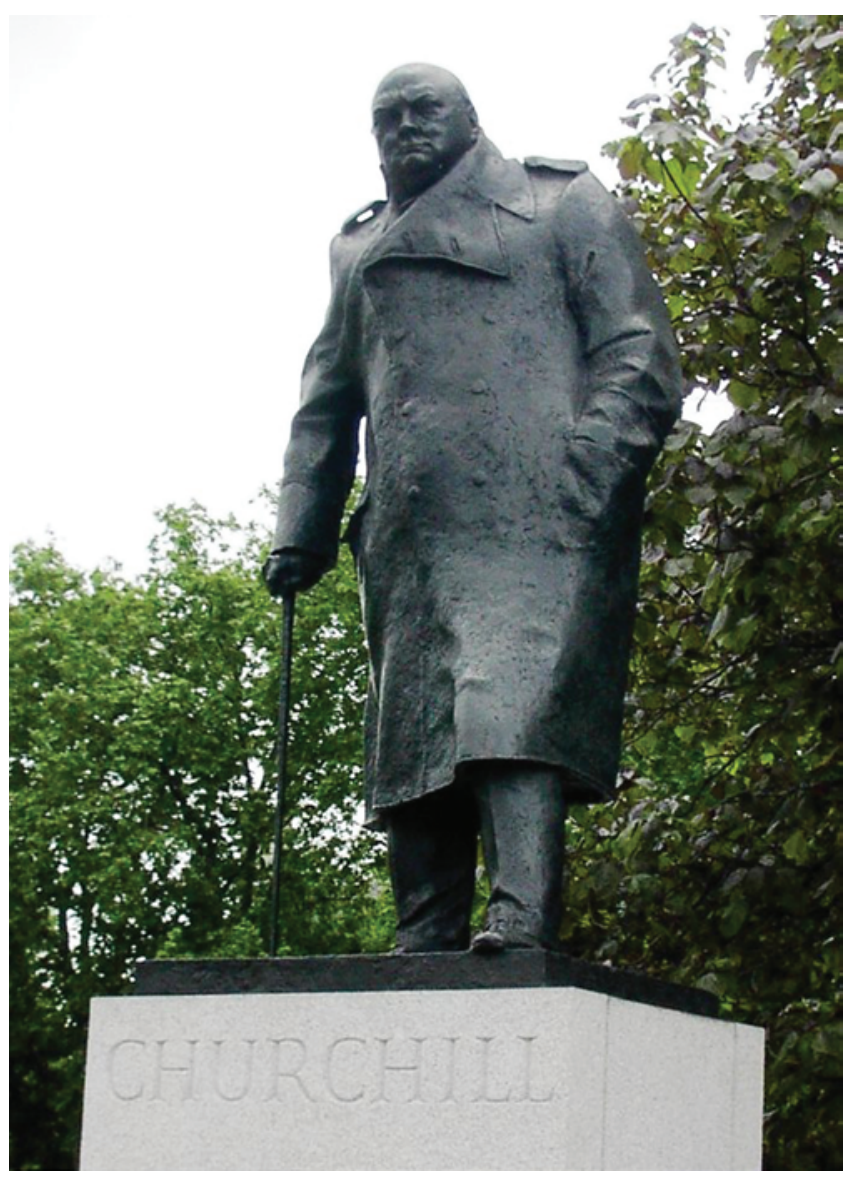

FIG. 7. Churchill's legacy is honored with this statue, which stands in Parliament Square. Source: https://en.wikipedia.org/wiki/Honours_of_ Winston_Churchill. Public domain.

tant meetings of the past century, as it laid the groundwork for not only the end of WWII but also for a new style of cooperative international diplomacy, a model that exists to this day. Its participants-Franklin Roosevelt, Winston Churchill, and Joseph Stalin-are among the most influential men of the modern era. The illnesses that so greatly affected them, thus, had a major effect on history and should not be ignored when examining the course of human events in the later part of the 20th century. Stalin's stroke marked the end of a brutally murderous regimen, and Churchill's deteriorating physical condition forced him to step out of public office prematurely, which in hindsight appears to have been detrimental to British foreign relations. Additionally, Roosevelt's worsening cerebrovascular health dulled his cognitive ability at the critical closing period of WWII, exactly when strong American leadership was needed to effectively help rebuild war-torn Europe and East Asia.

Interestingly, there was great secrecy that surrounded these leaders' health, as all 3 men acted to hide their physical condition from the media and general public. Premier Stalin killed physicians who evaluated his health and wrote negatively of it; during his last few years of life, his distrust of the medical community grew such that at the time of his death he was on the cusp of executing a plan to massacre doctors in Moscow. ${ }^{10,37}$ When Churchill experi- enced a severe stroke as prime minister in 1963, he did not disclose his stroke to either the media or Parliament, blaming exhaustion instead for his fatigue and brief period of absence. ${ }^{5}$ Lastly and perhaps most consequently, the fact that Roosevelt did not disclose his poor health despite being a democratically elected leader of a nation at war raises important ethical questions. ${ }^{27}$ Perhaps doing so would have helped smooth over communication challenges that occurred between the succeeding Truman administration and the Soviet Union following Roosevelt's abrupt passing.

\section{References}

1. Axelsson G: Nazi press calls death a 'miracle.' New York Times. April 15, 1945; 4

2. Barach AL: Franklin Roosevelt's illness. Effect on course of history. N Y State J Med 77:2154-2157, 1977

3. BBC: Churchill 'greatest PM of 20th Century'. January 4, 2000. (http://news.bbc.co.uk/2/hi/uk_news/politics/575219. stm) [Accessed May 13, 2016]

4. Beevor A: Berlin: The Downfall. New York: Penguin Books, 2004, p 528

5. Best G: Churchill: A Study in Greatness. London: Pimlico, 2001

6. Brain WR: Encounters with Winston Churchill. Med Hist 44:3-20, 2000

7. Bruenn HG: Clinical notes on the illness and death of President Franklin D. Roosevelt. Ann Intern Med 72:579-591, 1970

8. Burns JM: Roosevelt: The Soldier of Freedom. New York: Harcourt Brace Jovanovich, 1970

9. Churchill W: Letter to Henry R. Luce, December 6, 1956. Henry Luce Papers, Manuscript Division, Library of Congress (297). (https://www.loc.gov/exhibits/churchill/wccoldwar.html) [Accessed May 13, 2016]

10. Clarfield AM: The Soviet "Doctors' Plot" -50 years on. BMJ 325: 1487-1489, 2002

11. Dear ICB, Foot MRD (eds): Oxford Companion to World War II. Oxford: Oxford University Press, 2005

12. Dijilas M: Conversations with Stalin. New York: Harcourt Brace, 1962

13. Ellman M, Maksudov S: Soviet deaths in the Great Patriotic War: a note. Eur Asia Stud 46:671-680, 1994

14. Faria MA: Stalin's mysterious death. Surg Neurol Int 2:161, 2011

15. Ferrell RH: The Dying President: Franklin D. Roosevelt, 1944-1945. Columbia, MO: University of Missouri Press, 1998

16. Fredriksen JC: American Military Leaders. Santa Barbara, CA: ABC-CLIO, 1999, p 76

17. Gati C: The Stalinist legacy in Soviet foreign policy. Proc Acad Polit Sci 35:214-226, 1984

18. Gilbert M: Winston S. Churchill: Never Despair, 19451965. Boston: Houghton Mifflin, 1988, Vol 8

19. Gladdis JL: We Now Know: Rethinking Cold War History. Oxford: Oxford University Press, 1998

20. Grenville JAS: A History of the World from the 20th to the 21st Century. London: Routledge, 2005

21. Hachinski V: Stalin's last years: delusions or dementia? Eur J Neurol 6:129-132, 1999

22. Harbutt FJ: Yalta 1945: Europe and America at the Crossroads. Cambridge: Cambridge University Press, 2014

23. Harriman WA, Abel E: Special Envoy to Churchil and Stalin, 1941-1946. New York: Random House, 1975

24. Hart J: While America slept. National Review. September 15, 1989; p 32

25. Haynes M: Counting Soviet deaths in the Great Patriotic War: a note. Eur Asia Stud 55:303-309, 2003 
26. Heywood S: Churchill. New York: Routledge, 2003

27. Jones JM, Jones JL: Presidential stroke: United States presidents and cerebrovascular disease. CNS Spectr 11:674-678, 719, 2006

28. Keller B: Major Soviet paper says 20 million died as victims of Stalin. New York Times. February 4, 1989. (http://www. nytimes.com/1989/02/04/world/major-soviet-paper-says-20million-died-as-victims-of-stalin.html) [Accessed May 13, 2016]

29. Knight A: Beria, Stalin's First Lieutenent. Princeton, NJ: Princeton University Press, 1993

30. Kort M: The Soviet Colossus, ed 7. Amonk, NY: ME Sharpe, 2010

31. Laver J: The Modernisation of Russia 1856-1985. Oxford: Heinemann, 2002

32. Medvedev R: Let History Judge. The Origins and Consequences of Stalinism. Shriver G, trans. New York: Columbia University Press, 1989

33. Medvedev RA, Medvedev ZA: Khrushchev, the Years in Power. New York: Norton, 1978

34. Medvedev ZA, Medvedev RA: The Unknown Stalin. Dahrendorg E, trans. London: IB Tauris, 2003

35. Messerli FH: This day 50 years ago. N Engl J Med 332:1038-1039, 1995

36. New York Times: Last words: I have a terrific headache. New York Times. April 13, 1945; A1

37. Olsen B: [Murderers in white coats - the physicians' plot against Stalin.] Tidsskr Nor Laegeforen 117:4395-4398, 1997 (Norwegian)

38. Park BE: The Impact of Illness on World Leaders. Philadelphia: University of Pennsylvania Press, 1986

39. Radzinsky E: Stalin. The First In-Depth Biography Based on Explosive New Documents from Russia's Secret Archives. New York: Bantam Doubleday, 1996
40. Ramano-Petrova N: Stalin's Doctor, Stalin's Nurse. New Jersey: Kingston Press, 1984

41. Roosevelt FD: Address to Congress on Yalta (March 1, 1945). Miller Center. (http://millercenter.org/president/fdroosevelt/ speeches/speech-3338) [Accessed May 13, 2016]

42. Ross CG: 'Came out of the clear sky,' says President's physician. St. Louis Post-Dispatch. April 13, 1945; A2

43. Service R: Stalin: A Biography. Cambridge, MA: Harvard University Press, 2005

44. Tikhonov A: The end of the gulag, in Gregory P, Lazarev V (eds): The Economics of Forced Labor: The Soviet Gulag. Stanford: Hoover Institution Press, 2003, pp 67-73

45. U.S. Department of State: The Yalta Conference, 1945. Milestones in the History of U.S. Foreign Relations. (https://history.state.gov/milestones/1937-1945/yalta-conf) [Accessed May 13, 2016]

\section{Disclosures}

The authors report no conflict of interest concerning the materials or methods used in this study or the findings specified in this paper.

\section{Author Contributions}

Conception and design: Steinberg, Ali, Connolly. Critically revising the article: all authors. Reviewed submitted version of manuscript: all authors.

\section{Correspondence}

Gary K. Steinberg, Department of Neurosurgery, Stanford University School of Medicine, 300 Pasteur Dr., Stanford, CA 94305-5327. email: gsteinberg@stanford.edu. 